\title{
USING INFORMATION TECHNOLOGIES FOR BRIDGE MANAGEMENT IN MEXICO'S ROYAL ROADS BUILT BETWEEN XVI AND XVIII CENTURY
}

\author{
ANDRÉS A. TORRES-ACOSTA ${ }^{1 *}$, JOEL BUSTAMANTE-ALTAMIRANO ${ }^{2}$ AND \\ ALICIA ESPARZA-CARRILLO ${ }^{2}$
}

\author{
${ }^{1}$ Instituto Tecnológico de Estudios Superiores de Monterrey, Campus Querétaro (ITESM) \\ Campus Querétaro Epigmenio González 500, San Pablo 76130, Santiago de Querétaro, Qro., México. \\ e-mail: atorresa@tec.mx , www.tec.mx/en/queretaro (*corresponding author) \\ ${ }^{2}$ SATELSA SA de CV \\ Paseo de la Reforma 184, Lomas del Marqués 76146, Santiago de Querétaro, Qro., México. \\ email: joel.bustamante@satelsa.com.mx, alice_ec7@hotmail.com,www.satelsa.com.mx/
}

Keywords: Historical bridges, Royal Road, Information Technologies

\begin{abstract}
After the establishment of the Viceroyalty of New Spain in the $16^{\text {th }}$ century, the interest in precious metals and the mining activities would influence the emerging economic activities and the communications network of the New Spain. All the communications were built based on two mutually perpendicular axes. The first axis, East to West, between Veracruz-Mexico-Acapulco and the other axis, north to South, linked the northern region of the Viceroyalty with Mexico City and to Oaxaca and Guatemala. As part of the road infrastructure needed to get a continuous flow of goods, bridges were very important for crossing rivers, cliffs, and mountains. The fabrication of these structural elements were mainly made using the roman old school. The geometry, length, and materials used were varied, depending on the technical improvements of the time, and local labour expertise. The Vice-regal bridge vestiges are now scattered in the 2 million square $\mathrm{km}$ of the Mexican territory. Most of them are still in use, but others were forgotten in the old Royal Roads when they went out of use. This investigation deals with the methodology used (based on information technologies) to create a web-based management system for Viceregal bridges, that is now available to be used in Mexico by the three government levels (Municipality, State, and Federal) and research institutions.
\end{abstract}

\section{INTRODUCTION}

\subsection{Royal Roads}

Mexican pre-Columbian societies mainly used footpaths for trade and to move to different places. Since they ignored the usage of the wheel and pack animals, their means of transportation was by foot. The tamemes were in charge of transporting any items or merchandise from one place to the other by foot; they could lift around 23 kilograms in their backs and could reach as far as Guatemala.

When central Mexico was conquered by a small group of Spaniards, an extensive period of conquest began in the land. The Conquistadors opened bridle paths made of dirt in order 
reach the different indigenous populations with their horses and subdue them to the Spanish crown. In these early stages, they were content with merely broadening the existing preColumbian roads so that the horses, then unknown in the New World, could transit.

During the Viceroyalty $\left(16^{\text {th }}-18^{\text {th }}\right.$ centuries $)$, the interest for different products, substantially modified the network of exchange and drove the conquerors to open new roads to be able to travel to regions of difficult access. During this period, the most prominent case was the mining activity and mainly the extraction of silver. New regions were turned into colonies and road networks were shaped according to the locations of the mining reales or centers, with the purpose of exporting the products from the mines. As part of this process, other activities (agriculture, ranching, certain types of manufacture needed for the daily life and trade) surfaced as they were indispensable for the continued exploitation at the mining sites since they provided consumption goods for the workers and the raw materials for the mining activities. As new seams were discovered or as mining centers were consolidated, population centers emerged and roads with their corresponding branches were opened around them. [1]

From the 16th century, when the conquerors settled in the different regions of the New Spain, the New Kingdom of Galicia, New Biscay, New Santander and the New Kingdom of León, new routes for the transport of merchandise were opened. Communications during the Viceregal period were built based upon two perpendicular axes. The first one was outlined from Orient to Occident, between Veracruz- México- Acapulco/ Navidad and it constituted a colossal bridge between the Atlantic and Pacific oceans, known back then as the North Sea and the South Sea, respectively. The other axis, North-South, united the norther regions of the Viceroyalty with Mexico City as well as with Oaxaca and Guatema
communication were called Caminos Reales or Royal Roads;
built and they were known as:
Royal Road of México-Veracruz or "Viceroys Royal Road" Royal Road of México-Acapulco or "Royal Ror "Tóxior

Royal Road of México-Santa Fe or "Interior Land Royal Road" and

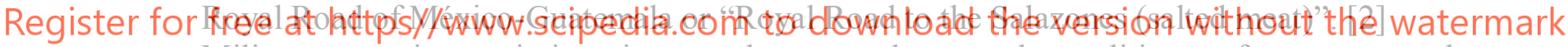

Military campaigns, missionaries, merchants, stockmen and expeditionary forces streamed from these roads carrying seeds, creeds, customs, culinary traditions, rituals, ideas and knowledge that came from different places and they established in the New Spain and its provinces a complex economic and cultural system that resulted in the building of cities, villages, baserris, haciendas, ranches, presidiums, hospitals, convents, and mining centers from where the precious metals, that for a long time supported the economy of the old continent, were extracted.

In the beginning, the means of transportation were the same people that travelled the roads (tamemes and armies) then, after the arrival of the conquerors, the usage of draught animals (horses, mules, oxen, etc.) were responsible for the radical modifications that the outline and the constructive system of the roads underwent. In a similar manner, this modernization in the field of land communications did not only modify the outline of the roads but also their outfitting.

The clash between the pre-Columbian and the European cultures, the shifts in economic activities and the introduction of different means of transportation resulted in changes to the road network existing prior to the conquest; these changes went beyond the creation of new roads. The outfitting of the Royal Roads corresponded to the purposes these roads served (e.g. 
transport of minerals, raw materials, foodstuffs, textiles and many other products; transit of people for cultural and religious purposes).

The Royal Roads are of considerable extension that stretches through an ample variety of physical settings and weathers (the Royal Road of the Interior Land is the longest of the Royal Roads with a length of $2600 \mathrm{~km}$, spread over 11 states); conflicts with the indigenous population persisted throughout the Viceroyalty in different regions surrounding the roads. In short, the outfitting of these roads needed to provide safety both for the travelers and their loads, shelter from the elements and for rest and points were provisions could be found. The lodging structures so that the travelers could rest, spend the night, change mules, and get provisions consisted of ventas, mesones, and inns; the outfitting on the road itself consisted of abreuvoirs, watch posts, post houses, fortifications, check points and bridges. [3]

\subsection{Bridges}

It is believed that the first bridges used by humans were natural formations, subsequently imitated by humans in their processes of settlement and movement through the land: rock formations of fortunate shapes, dimensions and placements, fallen tree trunks and protruding tree roots. In Mexico, a notable example of such bridges is Puente de Dios (God's Bridge) which is a rock formation at $80 \mathrm{~m}$ over river Amajac in the state of Hidalgo. [4]

The pre-Columbian footpaths were transited by people and therefore were gradually flattened and shaped by the passage of the travelers; it didn't matter if the routes were not made out of the materials at hand to solye immediate obstacles formations. However, or roads found in the city outfitted with bridges maintaining the hierarct
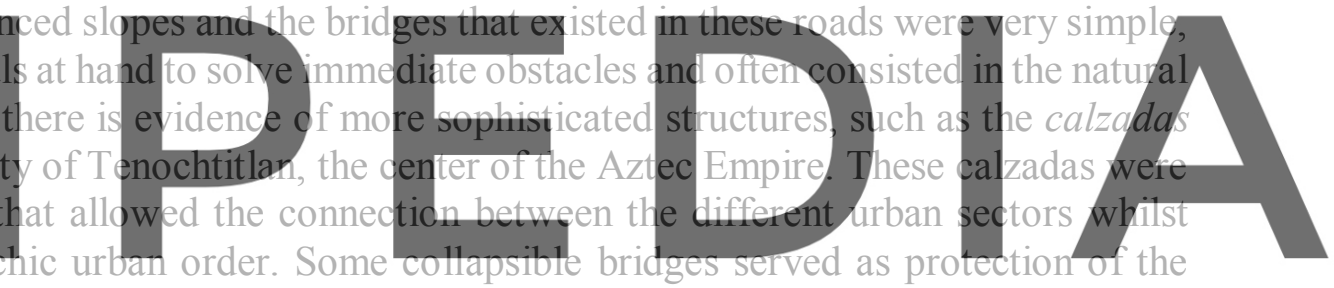
city. Bridges played an important role in the conquest of the city and the exploration of

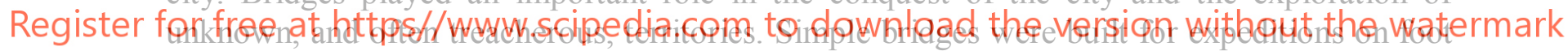
and by horse. [5]

With the establishment of the Viceroyalty of New Spain and other kingdoms within the Spanish Empire new ways of life emerged in the territory. These changes covered all aspects of life: religion, art, cuisine, economic activities, technology and the road networks. The arrival of horses, pack mules and carts came to substitute the tamemes during the $16^{\text {th }}$ century and both roads and bridges had to be widened, reinforced and built with subtler slopes so that the pack animals could go through easily, thus ensuring the safety of the travelers and their loads. [6]

In modern times, transformations in the roads, highways and their outfitting are still ongoing as an updating process to the network of roads in the country. In these updates, new roads are frequently outlined, the number of lanes are widened in the existing roads, and materials initially used for the construction are modified and/or replaced. [7] Communities and communication infrastructure (such as bridges) emerge into the spotlight and vanish or lose prominence as the ever-shifting needs of the population demand a constant updating of the roads. The road infrastructure can be used as an analytical element to trace the social, economic and technical changes within a society; the bridges are especially significant because they exhibit the evolution and refinement of constructive systems and the cunning of human beings 
to solve the obstacles present in the physical setting. On top of that, bridges often display the prevailing aesthetic elements of a society within a specific time frame through the architecture, craftsmanship, the materials used for construction, and ornamentation. [8]

The Royal Roads are regarded as the communication arteries of the Vice-regal society for the cultural and economic impact they had on the general society of the New Spain through the centuries of its existence. The bridges, being part of these road's infrastructure, played an important role in the flow of merchandise, people, customs, creeds and knowledge through the territory of the New Spain.

The information that Vice-regal bridges could provide to diverse fields of knowledge and disciplines is one of the main reasons for performing a research on them but also in an effort to preserve this constructions and their legacy, highlighting their cultural and historic value through research and the dissemination of the results.

\section{DPORI EM STA TEMENT}

In Mexico, property with historical value is regulated by the INAH (National Institute of Anthropology and History, by its acronym in Spanish), an institution directly dependent on the federal government of Mexico. This institute owns information regarding all the historical properties in the country and such information is deposited in an inventory generated by each INAH office (being 31 offices in total, one for each of the 31 states in Mexico). Bridges built during the Vice-regal period ( $16^{\text {th }}$ to $\left.18^{\text {th }}\right)$ are some of the structures included in the INAH's

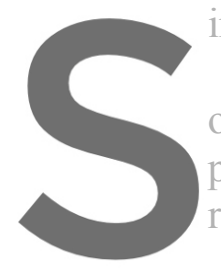
inventory.

This inventory ind outlines, photos (no nit

properties included

relegated to an obser

The inventories gencrated by each of the 31
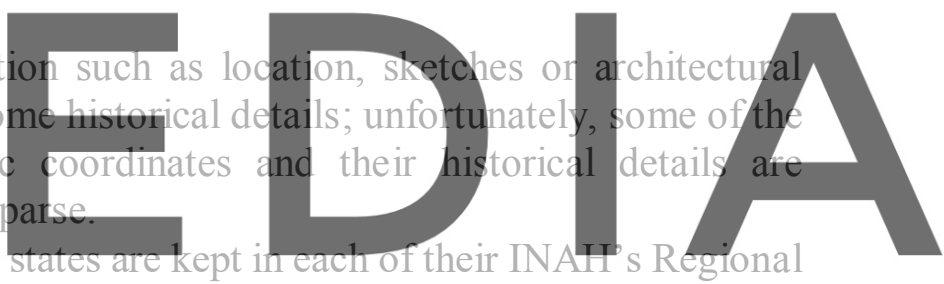

Centers as well as in the General Co-ordination of Historical Monuments of the INAH, in

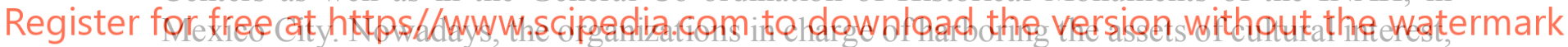
have diverse typologies and capacities, which leaves them in the position of having to manage them in an effective way with very limited resources. The information they have is diversified, decentralized and, fundamentally, in paper support and, rarely, in digital support. In the latter's case, it is not always under standardized formats and safeguarded by one entity.

While an investigation regarding the Vice-regal bridges in the Royal Roads could prove very useful for any potential initiatives of salvaging and/or repurposing these historic bridges as well as to generate other research projects related, it is difficult to gather and process all the information for its subsequent analysis, also the data contained in the inventories can be either incomplete, obsolete, incorrect and sparse in many cases. The changes that the road networks undergo through the years usually result in leaving communities, stretches of roads and structures to fall into oblivion with outcomes such as disrepair and, in many cases, complete loss of the structures and thus no material evidence of their existence.

It is a central necessity to build an updated inventory of these bridges using both the information provided in the inventories and the usage of digital resources, spatial research and georeferencing to complete the existing information and generate new, important information regarding these structures. Information and Communications Technologies will be employed 
with the purpose of divulging the results to the general public, research institutions and government agencies and thus be able to safeguard and broadcast the heritage that these historical bridges have to offer.

\section{THE RESEARCH PROJECT}

The project starts in 2011 as an independent initiative with the objective of creating a catalog/ inventory of the bridges constructed in the Vice-regal period ( $16^{\text {th }}$ to $18^{\text {th }}$ century) and determine which bridges are located on the route of the Royal Road of the Interior Land or the Silver Route. The project started with the reconnaissance of few bridges, most of them in the State of Querétaro: Bridge of Calesa, Bridge of Juárez, Bridge of Sauz (Pedro Escobedo), Bridge of History (San Juan del Río), as well as two other bridges outside of this state: Bridge of Atongo (Tepeji del Río, Hidalgo) and Bridge of Tres Guerras (Celaya, Guanajuato). For this reconnaissance, trips were conducted over the corresponding stretches in the Royal Road and information, such as geographic coordinates, construction materials, physical state of the structure and photographic evidence, was collected.

During these trips, some bridges of which there was no previous knowledge were found as well as others whose current state was in disrepair and were out of use. For this reason, a request was issued to the INAH in the matter of obtaining a catalog of the bridges in Mexico to get acquainted with their condition and location. The provided information includes around 850 fact sheets of registered bridges.

While a transcription

of information or precise

In terms of location,

structure can be found.

sketches that provide ad

of the work sheets, how
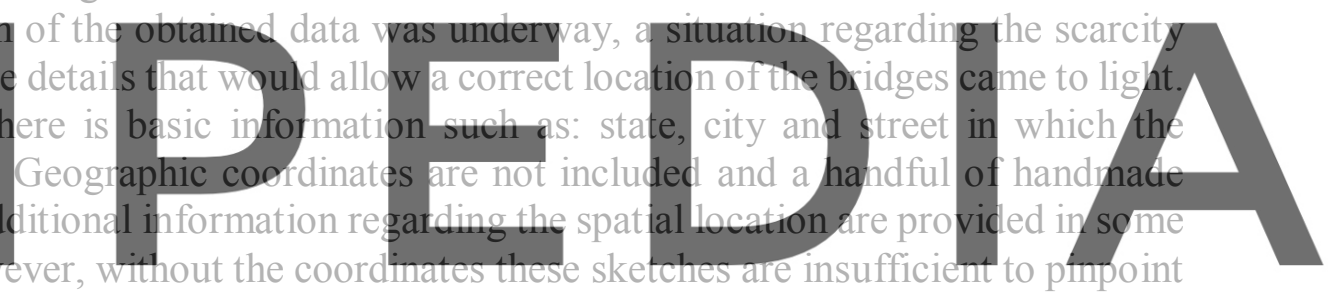

the structures' precise location.

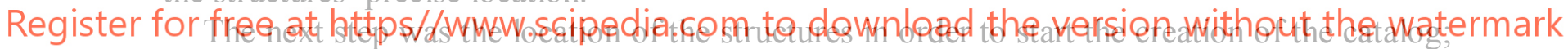

it was determined that only structures catalogued under the Vice-regal period ( $16^{\text {th }}$ to $18^{\text {th }}$ )

would be identified and worked on. Since the project is an independent initiative and the information collected is of national level there weren't enough resources to perform a direct search (fieldwork) and georeferencing of most of the registered bridges.

Another limitation for a direct reconnaissance of some the bridges is the accessibility to the structures since they may be covered from view by excess of weed; passable roads may not be available and other blockages such as barbed wire and fences for cattle may be present. There are cases in which there are no vestiges of the structures to be found or the structure could be inside private property or restricted government property thus making it inaccessible to the general public.

For the cases in which direct georeferencing is out of question, a researcher with knowledge and experience in the use of information technologies such as GIS applications, was tasked with locating each of the bridges using primarily the satellite maps and information on roads and highways contained in the Google Earth program. All the considered structures were individually tracked using the information provided by the INAH regarding all matters of their location. Information gathered from historical manuscripts, statistical memoirs, books 
specialized in historical and cultural properties in the country, travel journals from the $18^{\text {th }}, 19^{\text {th }}$ and $20^{\text {th }}$ centuries as well as historical cartography was collected and reviewed to complement the information in the fact sheets and aid in the location of some of these bridges.

\subsection{Remote location and georeferencing of the bridges}

A classification system was determined based on a range of accuracy of location present in the georeferencing of each bridge. First, a starting point is determined using the information provided in the fact sheets or by using the satellite maps and the tools included in Google Earth. This classification is based on a range of distance from the starting point, in which the structure can be found, and it is the following:

In GREEN are the identified bridges that can be found in a $100 \mathrm{~m}$ radius from the starting point. These bridges may or may not be visible in the satellite map but using tools such as Street View it is possible to establish a point where the bridge is or was constructed. Some of these bridges may be completely hidden from sight because they are surrounded or covered by modern structures.

In ORANGE are the bridges that could not be identified via satellite maps at first instance and significant information on them in other sources could not be found, other than the information provided by the fact sheets. This information was used to establish the starting point. It was determined that these structures could be located within a 101-500 m radius from the starting point

In RED, all the re the minimal data could street names and sketd determined that the poin any referenced street.
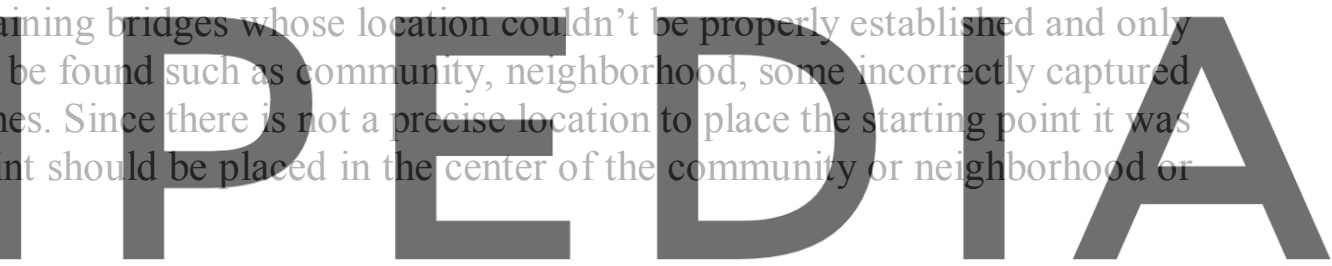

Register for free at https//www.scipedia.com to download the version without the watermark

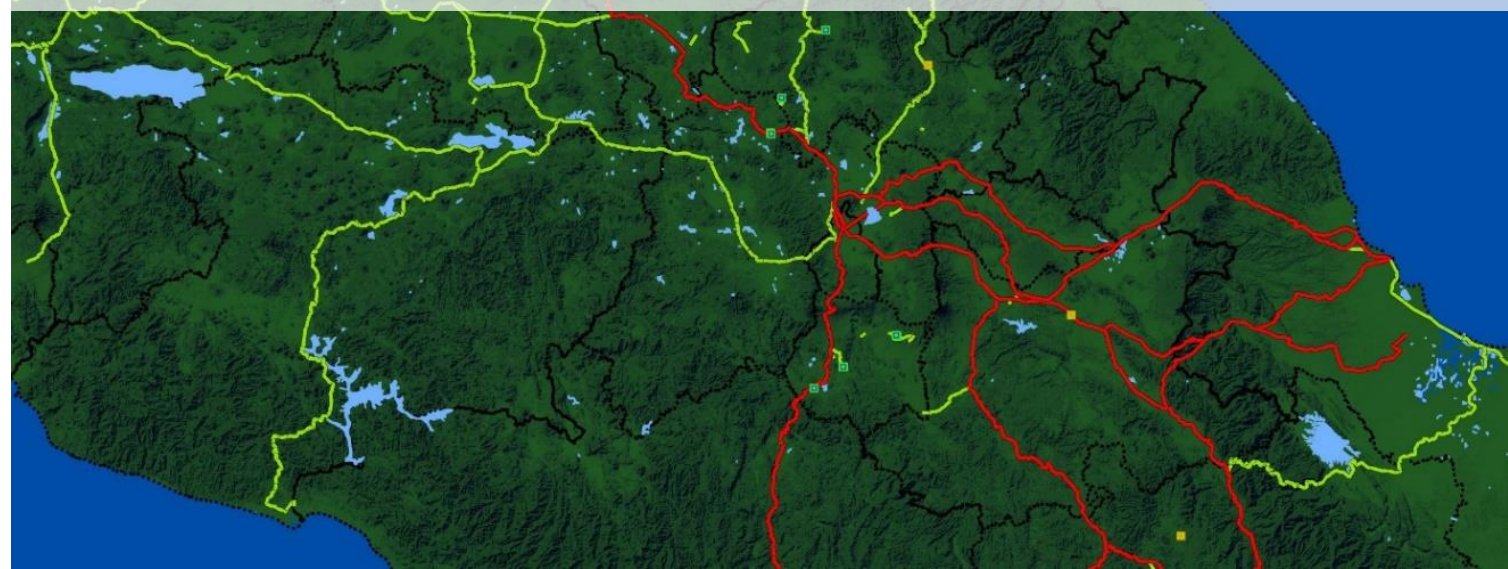

Figure 1. $16^{\text {th }}$ century bridges. The red lines indicate the Royal Roads and the green lines indicate transversal roads. The bridges built during the $16^{\text {th }}$ century and that could be identified with varying accuracy are marked in 
squares. The squares employ the color classification system previously mentioned. There is a total of 15 identified bridges built during the $16^{\text {th }}$ century.

It can be noted that many of the bridges marked in green can be found near modern roads and highways. Some of these bridges are still in use and in other cases, modern bridges and structures were built near the old bridges for their replacement, making their preservation possible. A notable case is the Bridge of la Laja or Bridge of Tres Guerras in the entrance of Celaya, Guanajuato.

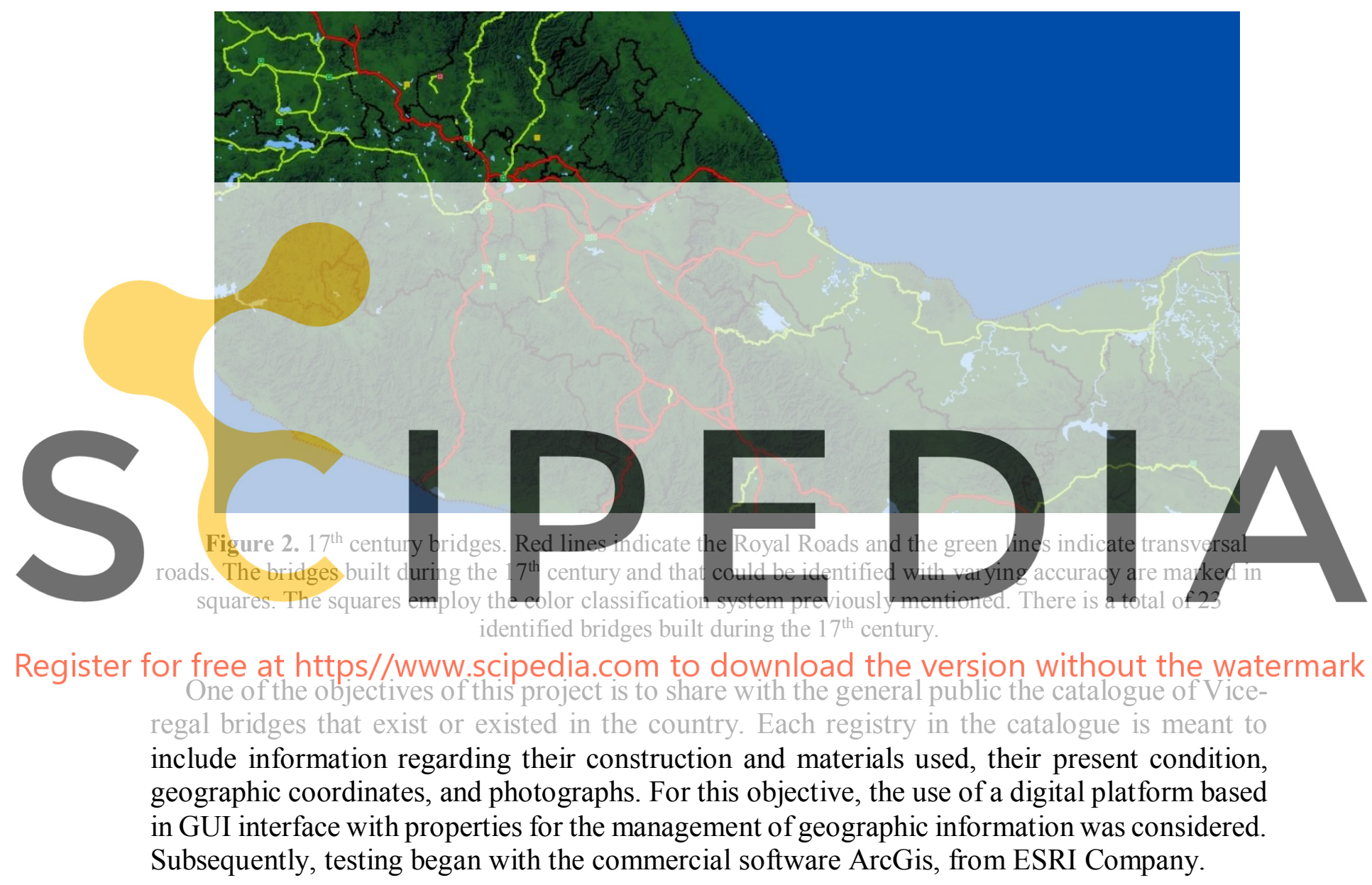




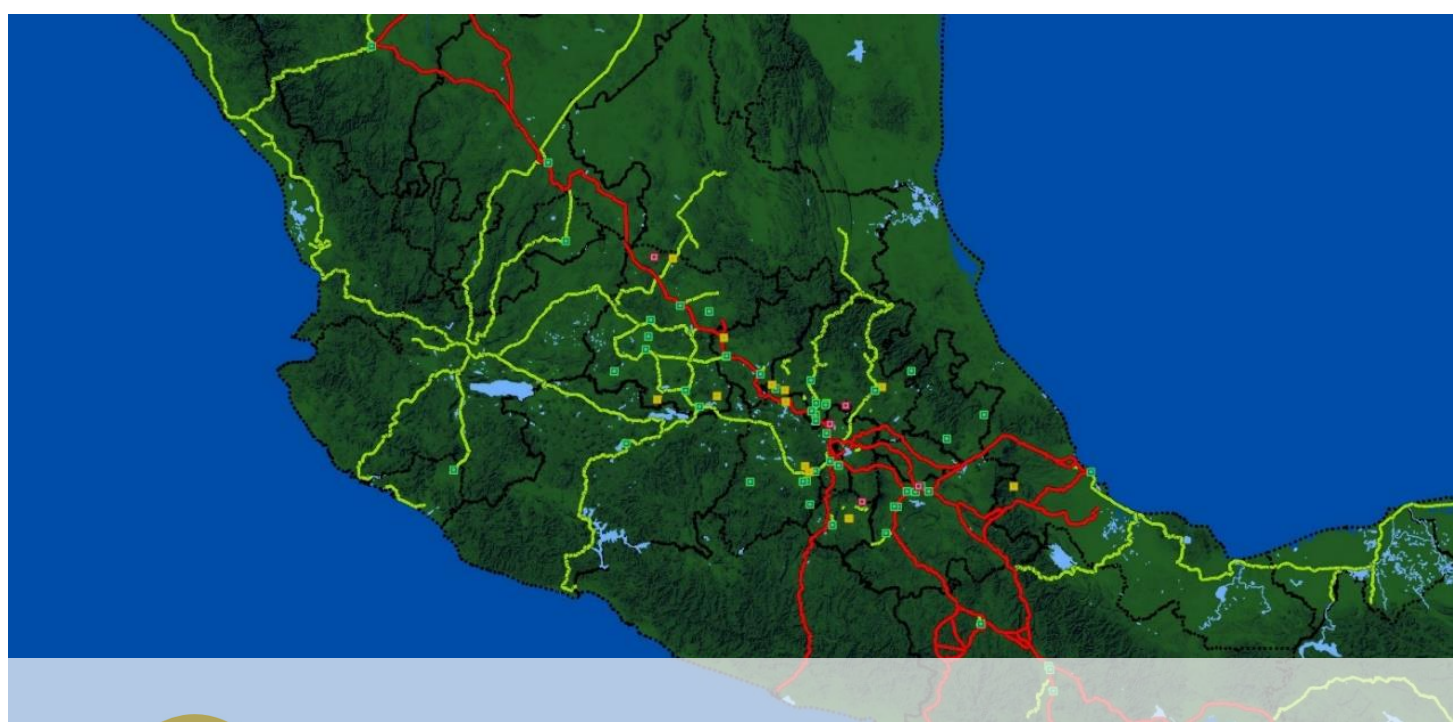

Figure 3. $18^{\text {th }}$ century bridges. The red lines indicate the Royal Roads and the green lines indicate transversal oads. The bridges built during the $18^{\text {th }}$ century and that could be identified with varying accuracy are marked in squares. The squares employ the color classification system previously mentioned. There is a total of 81 identified bridges built during the $18^{\text {th }}$ century.

\subsection{Platform generation}

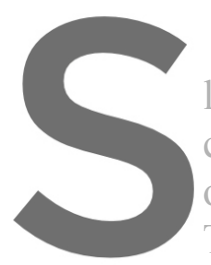

Once the graphic inte layer corresponding collected from the work operating in the software (DBF) to subsequent y 1 (n) This information can be consulted by applyin

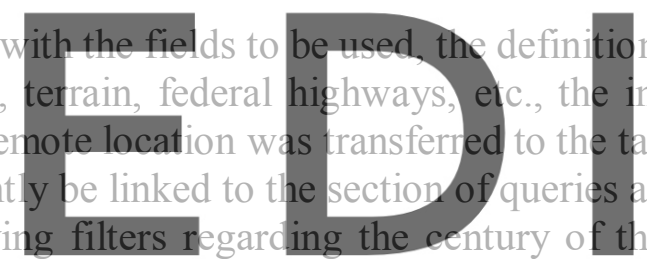
tions for each
e information
sable format
f the bridge's construction and location by state. Afterwards the structure of interest can be selected from a

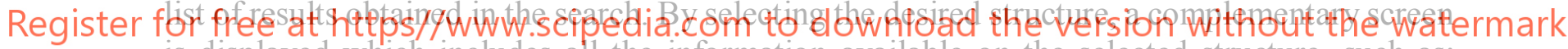
is displayed which includes all the information available on the selected structure, such as: general observations on the structure, commentaries made by the local population, bridge's condition, type of structure, entity to which it belongs (government or private) and any other detail obtained as well as the photographic archive, if available. 


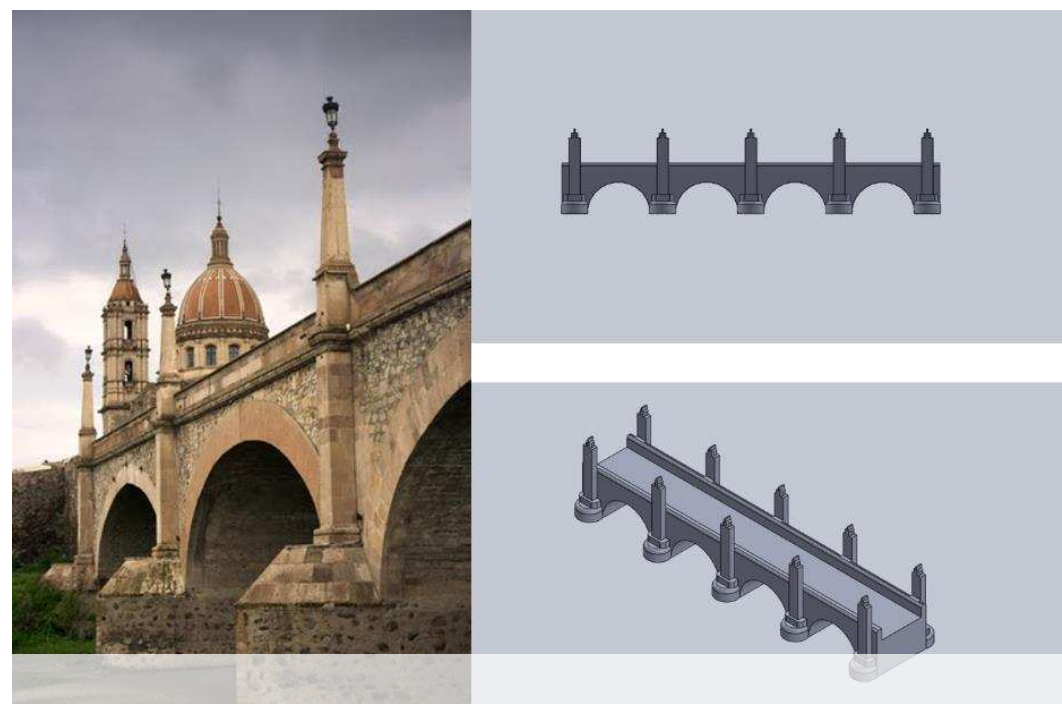

Figure 4. Bridge of Lagos. Built during the $16^{\text {th }}$ century built in the city of Lagos de Moreno, in the municipality of Lagos de Moreno in Jalisco. At the top right is the elevation projection of the bridge drawn for this project and at the bottom right is the isometric projection.
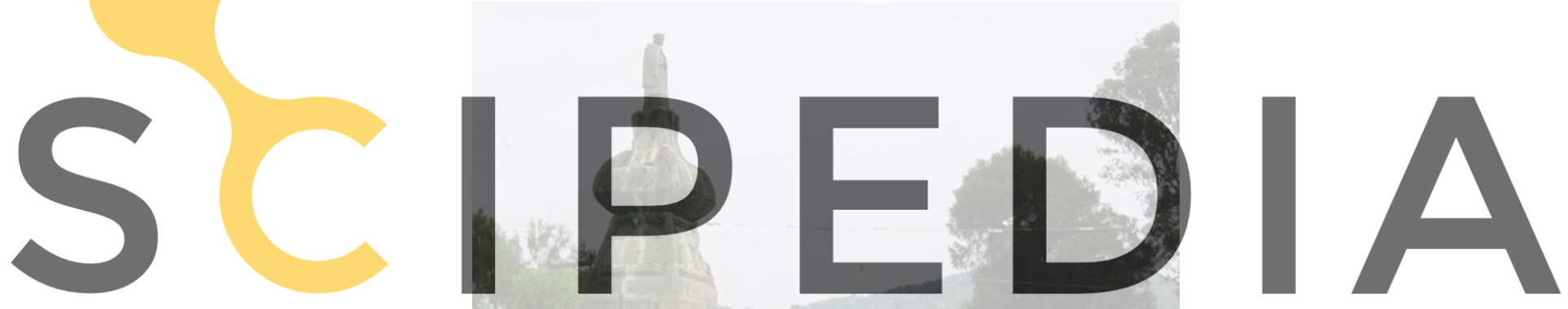

Register for free at https//www.scipedia.com to download the version without the watermark

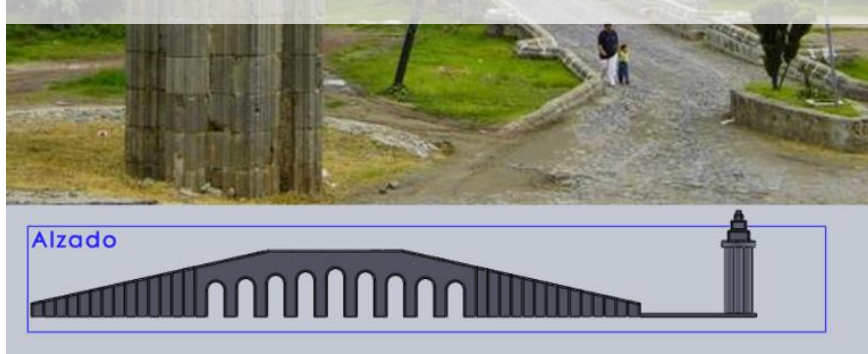

Figure 5. "Puente Grande" or Big Bridge. Built during the $18^{\text {th }}$ century in the city of Acámbaro in the municipality of Acámbaro in Guanajuato. In the bottom is the elevation projection of the bridge.

During the testing stage, the downsides of this software became evident.

- ArcGis is a commercial software that requires a license per computer for personal use and a special license for online usage. 
- Aside from the high cost that obtaining and using the sofware implies, its usage requires a certain degree of previous knowledge on the software.

Both situations are incompatible with the contemplated objective of making the results of this project available to the general public or any person interested in the Vice-regal bridges leaving this tool to be discarded while alternatives were searched for. The best option came to be the development of a web based application of free access that can be consulted by means of any electronic mobile device and in which the information displayed can be supoorted by the majority of browsers.

Using technology such as Apache Web Server as setting to host all the information gathered, web pages, images, 3D models and others. MySQL was used as the engine to manage the information in Database, PHP was used for the dynamic handling and structure of the site; JQuery and JS were used for the dynamic handling but from the user's perspective. By using all of these technologies, it is not necessary to be limited to an specific operating system like Linux, Windows or Mac.

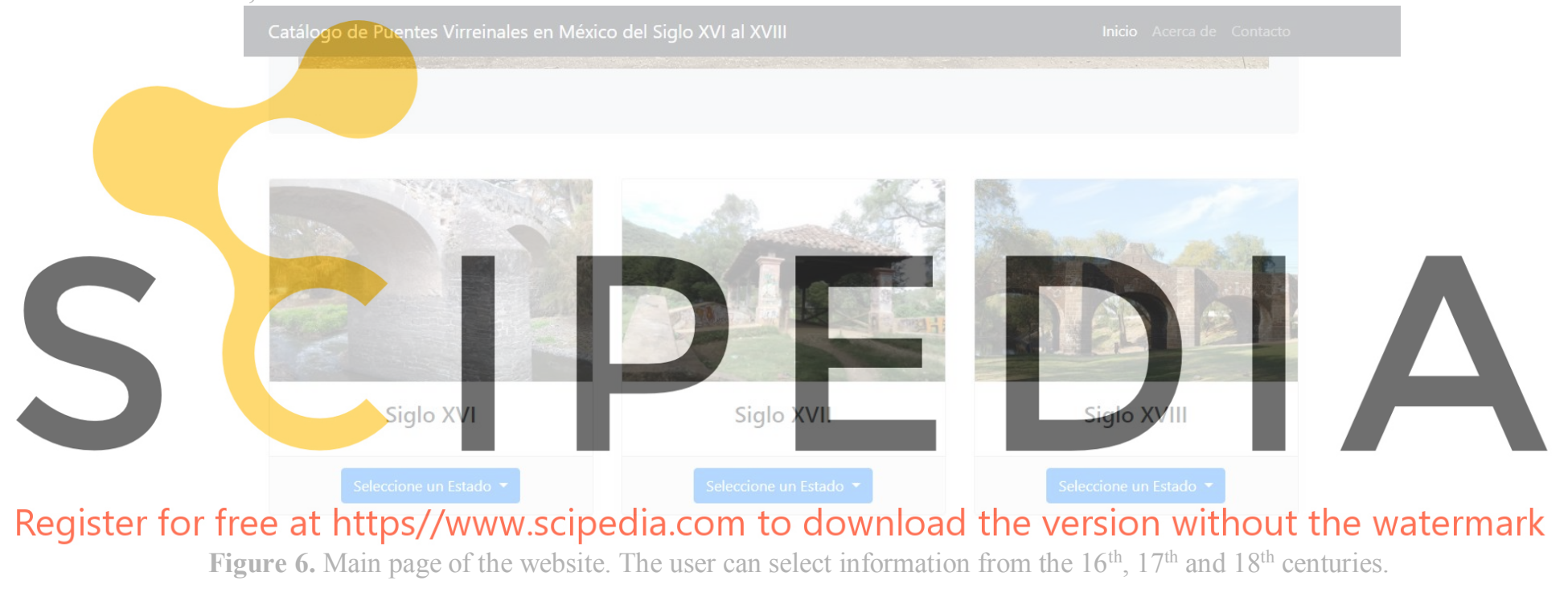

The web-based application development phase of the project is ongoing in order to provide the user with the most information possible. However a site has already been set up and it contains some of the information collected. 

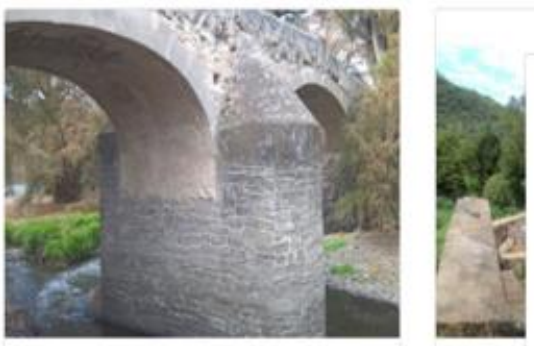

Siglo XVI

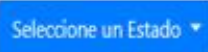

Seleccione un Estado *

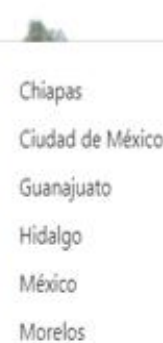

Puebla

Querétaro

Seleccione un Estado
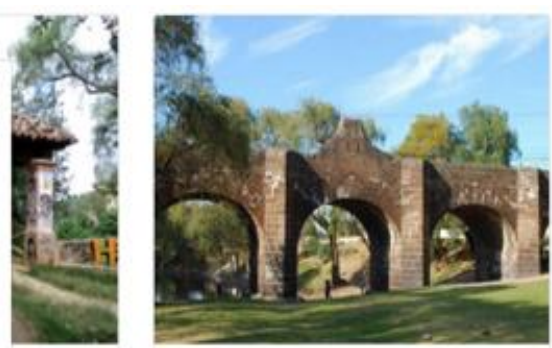

Siglo XVIII

Seleccione un Estado *

Siglo: XVII

Puentes registrados en el Estado de: Querétaro

\begin{tabular}{|c|c|c|c|c|}
\hline " & Municipio & Comunidad & Nombre del inmueble & Representación 3D \\
\hline 1 & Tequisquiapan & San Nicoll's & Puente de Fray Sebastián de Aparicio & NO \\
\hline
\end{tabular}

Figure 7. Drop-down list displaying the states available for browsing regarding bridges from the $17^{\text {th }}$ century. Also pictured is the result obtained by selecting the state of Querétaro.

It is intended that the platform be an interactive space where the public can share information in the platform either through a blog or a forum thus enlarging, improving and updating the information.

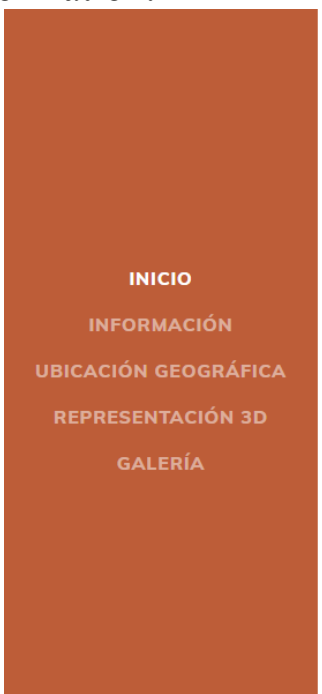

\title{
PUENTE DE FRAY SEBASTIÁN DE
} APARICIO

\author{
TIPO DE PROPIEDAD SIN USO · CLAVE INAH 220170160002 · FOLIO 75304
}

AL PONIENTE DE LA COMUNIDAD DE SAN NICOLÁS · COLONIA NO DISPONIBLE · SAN NICOLÁS · TEQUISQUIAPAN REFERENCIA

Figure 8. Page displaying the information of the Bridge of Fray Sebastián de Aparicio in the municipality of Tequisquiapan, Querétaro. The panel on the left side provides the browsing options: information (which includes, when available, oral and documentary data as well as any details of interest noted by the researchers such as inscriptions and physical state of the structure), geographic location- coordinates, 3D rendering and photographic gallery. 
The site can be accessed and consulted through the following link: http://sgpa.desacomp.com and any comment or suggestion can be submitted to the address: joel.bustamante@satelsa.com.mx

\section{CONCLUSIONS}

Providing the obtained information as well as providing means of interaction with the public will not only serve to complement the information presented but to link the public to the historic bridges, considering their artistic, social, and cultural importance. If the public, along with the government institutions and other organizations involved with historic and cultural heritage, are aware of the heritage still standing in the country and its value, perhaps an invigorated interest in the repurpose and preservation of these structures could arise.

Acknowledgements. Authors acknowledge collaboration from the Grupo Camino Real de Tierra Adentro en Querétaro: Rosa Estela Reyes, Virginia Guzmán Monroy, García, Cynthia Leija Sánchez, Eva Lilia Acosta Garnica, Centro INAH Qro; Frida Sarete Orozco Loeza, José Ignacio Urquiola Permisán, Marja González Juárez, Gaspar Real Cabello, Universidad Autónoma de Querétaro. The authors greatly acknowledge the funding provided by SATELSA SA de CV as economical support given to the project since 2009. The opinions and findings in this paper are those of the author and not necessarily those of the funding agencies.

\section{REFERENCES}

[1] Tutino, J. Making a New World. Founding Capitalism in the Bajio and Spanish North America. Duke University Press (2011), pp. 159-208

[2] Escalante, P. Los Caminos del México Antiguo. In: Cramaussel, C. (Ed.): Rutas de la Nueva España, El Colegio de Michoacán (2006), pp. 28-36

[3] Cramaussel, C. El Camino Real de Tierra Adentro. De México a Santa Fe. In: Cramaussel, C. (Ed.): Rutas de la Nueva España, El Colegio de Michoacán (2006), pp. 301-303, 314323

[4] Ortiz, J., Hernández, J., González, J. and Esteva P. Puentes de México, Arte e Historia. Grupo Tolteca (1988), pp.7-10

[5] Ortiz, J., Hernández, J., González, J. and Esteva P. Puentes de México, Arte e Historia. Grupo Tolteca (1988), pp. 30-39

[6] Ortiz, J., Hernández, J., González, J. and Esteva P. Puentes de México, Arte e Historia. Grupo Tolteca (1988), pp. 69-73

[7] González de Cosio, F. Historia de la Obras Públicas en México, Volume I, Secretaría de Obras Públicas (1971), pp. 483-484.

[8] Avilés, M. and Brambila R. La puerta del camino a tierra adentro. En busca de evidencias materiales. In: Cramaussel, C. (Ed.): Rutas de la Nueva España, El Colegio de Michoacán (2006), pp. 330-337 